Trinity University

Digital Commons@ Trinity

Chemistry Faculty Research

Chemistry Department

2013

\title{
Sequence-Specific Inhibition of a Nonspecific Protease
}

Leigh A. Logsdon

Trinity University, llogsdon@trinity.edu

Adam R. Urbach

Trinity University, aurbach@trinity.edu

Follow this and additional works at: https://digitalcommons.trinity.edu/chem_faculty

Part of the Chemistry Commons

\section{Repository Citation}

Logsdon, L. A., \& Urbach, A. R. (2013). Sequence-specific inhibition of a nonspecific protease. Journal of the American Chemical Society, 135(31), 11414-11416. doi: 10.1021/ja406032x

This Post-Print is brought to you for free and open access by the Chemistry Department at Digital Commons@ Trinity. It has been accepted for inclusion in Chemistry Faculty Research by an authorized administrator of Digital Commons @ Trinity. For more information, please contact jcostanz@trinity.edu. 


\title{
Sequence-Specific Inhibition of a Non-Specific Protease
}

\author{
Leigh A. Logsdon and Adam R. Urbach* \\ Department of Chemistry, Trinity University, 1 Trinity Place, San Antonio, TX, 78212
}

\section{Supporting Information Placeholder}

\begin{abstract}
A non-specific exopeptidase, aminopeptidase $\mathrm{N}$ (APN), is inhibited sequence specifically by a synthetic host, cucurbit[7]uril (Q7), which binds with high affinity and specificity to Nterminal phenylalanine (Phe) or 4-aminomethyl phenylalanine (AMPhe) and prevents their removal from the peptide. Liquid chromatography experiments demonstrate that in the presence of excess Q7, APN quantitatively converts the pentapeptides Thr-Gly-Ala-X-Met into the dipeptides X-Met $(X=$ Phe or AMPhe). The resulting Q7-bound products are completely stable to proteolytic digestion for at least $24 \mathrm{~h}$. Structureactivity studies reveal a direct correlation between the extent of protection of an N-terminal amino acid and its affinity for Q7. Therefore, Q7 provides predictable sequence specificity to an otherwise non-specific protease and enables the production of a single peptide product. Conversely, APN uncovers a high-affinity epitope, which is then bound by Q7, and thus this approach should also facilitate the molecular recognition of peptides.
\end{abstract}

Methods for selective enzymatic digestion of peptides and proteins are crucial to many processes in molecular biology and biotechnology. Proteases are used widely to process polypeptides for sequencing ${ }^{1}$ and other applications in proteomics ${ }^{2}$ and medicine. ${ }^{3}$ Endopeptidases, which cleave the peptide backbone at nonterminal sites, typically have well-defined sequence specificity. Exopeptidases, which remove amino acids sequentially from a terminus, can be specific for a small set of amino acids or generally non-specific, which allows them to digest a peptide completely into amino acids. ${ }^{4,5}$ Developing methods that change the substrate specificity of proteases would broaden the scope of their applications. Here we show that a synthetic receptor, cucurbit[7]uril (Q7), can be used to impart specificity to an otherwise non-specific exopeptidase, porcine aminopeptidase $\mathrm{N}$ (APN), by binding to a specific residue and inhibiting its removal from the peptide.

Q7 is a highly stable container molecule that can associate noncovalently with a wide range of cationic organic guests in aqueous media with equilibrium association constant $\left(\mathrm{K}_{\mathrm{a}}\right)$ values of up to $10^{15} \mathrm{M}^{-1} .^{6-8} \mathrm{We}$ and others have studied the capacity of Q7 to bind to amino acids, peptides, and proteins and found that Q7 prefers to bind $\mathrm{N}$ terminal phenylalanine (Phe), tyrosine (Tyr), and tryptophan (Trp) residues, by incorporating the sidechain within the nonpolar Q7 cavity and chelating the $\mathrm{N}$-terminal ammonium group with Q7 carbonyl oxygens. ${ }^{9-14} \mathrm{Nau}$ and coworkers have shown that Q7 can slow the activity of an endopeptidase, trypsin, and an exopeptidase, leucine aminopeptidase (LAP), by binding to their respective substrates. ${ }^{15,16}$ In both cases, they observed only partial and short-lived inhibition. We hypothesized that this approach could be used to crop a complete sample of peptide down to the first Phe residue if the aminopeptidase could be inhibited exclusively at this position.

LAP was not completely inhibited by Q7,15,16 and thus we wanted to test a different aminopeptidase. APN was chosen for its lack of specificity, ${ }^{4}$ its medicinal relevance, ${ }^{17}$ and its commercial availability. The pentapeptide, ThrGly-Ala-Phe-Met (1), was chosen as the first substrate for APN digestion because it contains five different amino acid residues, including hydrophilic and hydrophobic sidechains, and it contains 

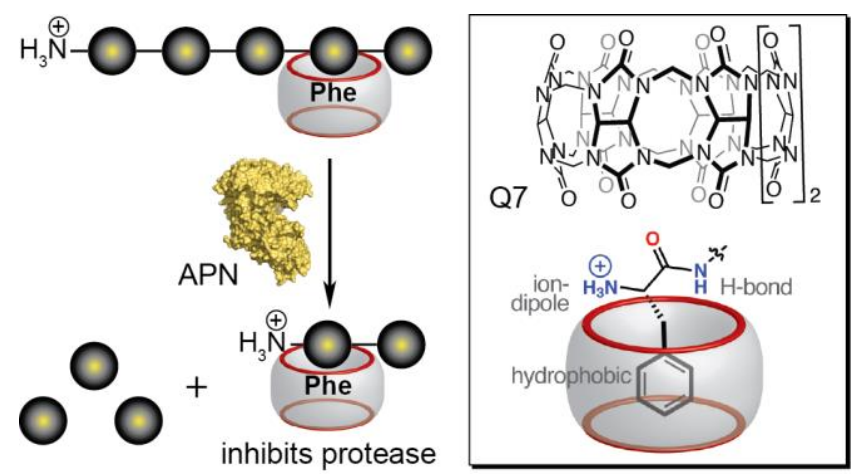

Figure 1. (left) Schematic illustration of the inhibition of APN-mediated peptide digestion at a Phe residue using Q7. (right) Chemical formula of Q7 and schematic of the molecular recognition of $\mathrm{N}$-terminal Phe.

a non-terminal Phe residue, which becomes the Nterminal residue after APN removes the Thr, Gly, and Ala residues (Figure 1). The entrance to the catalytic site of APN is highly constricted, and specific interactions are made with the sidechain of the terminal residue. ${ }^{18}$ Q7 should protect an $\mathrm{N}$ terminal Phe by encapsulating its sidechain and interacting directly with the terminal ammonium group (Figure 1). Peptide $\mathbf{1}$ and the predicted product of digestion, Phe-Met (2), were synthesized. These peptides and the others used in this study have C-terminal amides because they were synthesized on Rink amide resin.

Analytical HPLC was used to monitor the digestion of $0.50 \mathrm{mM}$ peptide 1 by $0.20 \mu \mathrm{M}$ APN in the absence of Q7 and in the presence of a substoichiometric quantity $(0.25 \mathrm{mM})$, a stoichiometric quantity $(0.50 \mathrm{mM})$, and a 2-fold excess $(1.0 \mathrm{mM})$ of Q7 (Figure 2). Samples were analyzed at reaction times of $5 \mathrm{~min}, 3 \mathrm{~h}$, and $24 \mathrm{~h}$. At the 5 min time point, we observed substantial degradation of the starting material (retention time 21-22 $\mathrm{min}$ ) in the absence of Q7 and at $0.25 \mathrm{mM} \mathrm{Q7,}$ and substantially slower degradation with $0.50 \mathrm{mM}$ and $1.0 \mathrm{mM}$ Q7.

At the $3 \mathrm{~h}$ time point (Figure $2 \mathrm{~b}$ ), all samples showed complete disappearance of starting material. Remarkably, only one peak (at $\sim 6 \mathrm{~min}$ ) remained in the HPLC traces of the samples containing $0.50 \mathrm{mM}$ and $1.0 \mathrm{mM}$ Q7. The broad shape and retention time of these peaks correspond exactly to those of a standard sample of the Q7 $\bullet 2$ complex, and electrospray ionization mass spectrometry (ESI-MS) confirmed the digestion product as

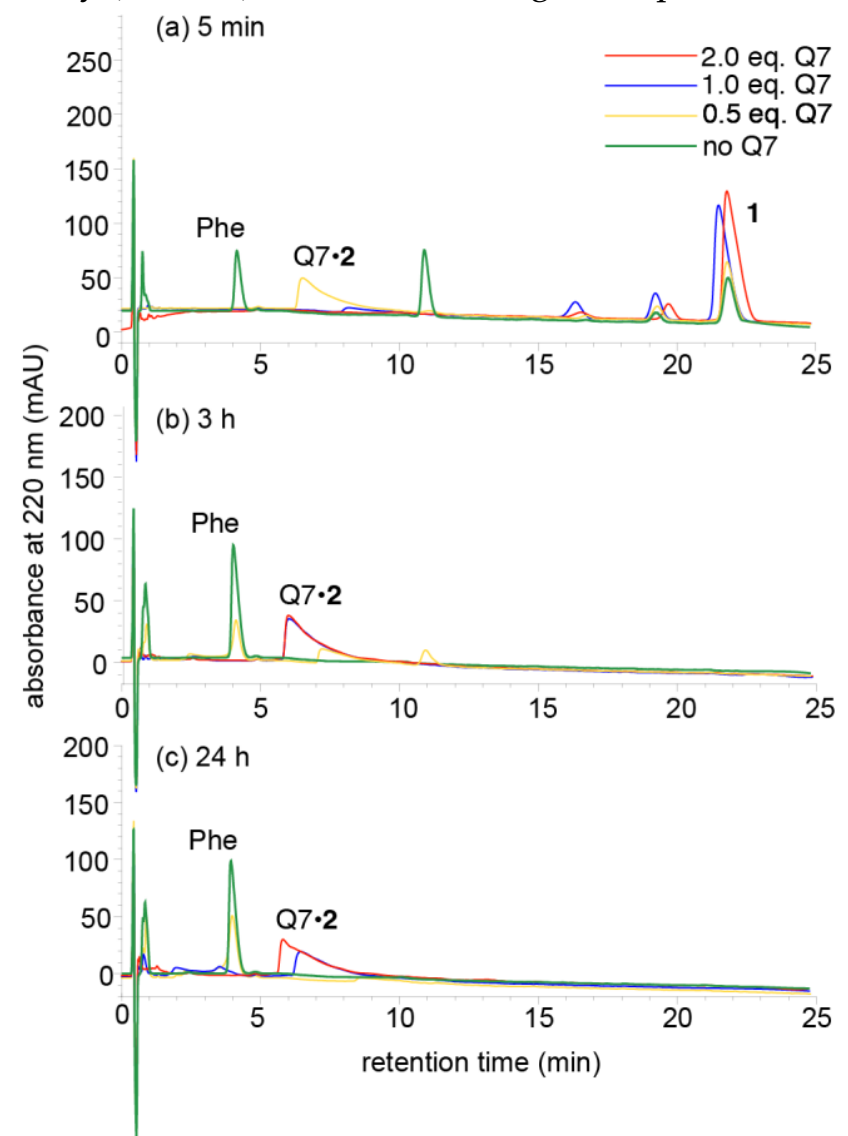

Figure 2. Analytical HPLC traces of the digestion of $0.5 \mathrm{mM}$ Thr-Gly-Ala-Phe-Met (1) with $0.20 \mu \mathrm{M}$ APN in the presence of $0,0.5,1.0$, or 2.0 molar equivalents of Q7 at $37{ }^{\circ} \mathrm{C}$ in $10 \mathrm{mM}$ ammonium phosphate, $\mathrm{pH}$ 7.2. Reaction times are (a) $5 \mathrm{~min}$, (b) $3 \mathrm{~h}$, and (c) $24 \mathrm{~h}$.

the Q7•2 complex (see Supporting Information). The conversion of pentapeptide $\mathbf{1}$ to the Q7•2 complex was quantified by comparing the area of the product peak with that of a standard sample of Q7•2. We observed quantitative conversion (101\% $\pm 1.1 \%$ and $98 \% \pm 1.3 \%$ ) in the presence of $1.0 \mathrm{mM}$ Q7 and $0.50 \mathrm{mM}$ Q7, respectively. With substoichiometric Q7 (0 or $0.25 \mathrm{mM}$ ), however, there was no substantial formation of the Q7•2 product. Instead, we observed a peak at $\sim 4$ min that corresponds to the free Phe amino acid.

At the $24 \mathrm{~h}$ time point (Figure 2c), there was no change in the HPLC trace of the sample containing $1.0 \mathrm{mM}$ Q7. This result indicates that the Q7•2 complex is highly stable under these conditions. In the sample containing $0.5 \mathrm{mM}$ Q7, we observed a $37 \%$ reduction in the area of the Q7 $\bullet 2$ peak. ${ }^{19}$ 
Therefore, an excess of Q7 is needed to protect the Q7 $\bullet 2$ product over longer periods of time.

Table 1. Peptide Protection vs. the Binding Constant.

\begin{tabular}{lrl}
\hline Peptide & $\begin{array}{c}\text { Residual } \\
\text { Peptide }(\%)\end{array}$ & $\mathrm{K}_{\mathrm{a}}\left(\mathrm{M}^{-1}\right)^{\mathrm{c}}$ \\
\hline Phe-Met (2) & $93.9( \pm 1.1)^{\mathrm{a}}$ & $1.4( \pm 0.1) \times 10^{7}$ \\
Phe-Met (2) & $100.4( \pm 1.4)^{\mathrm{b}}$ & \\
Tyr-Met (3) & $19.8( \pm 3.5)^{\mathrm{a}}$ & $6.4( \pm 0.4) \times 10^{5}$ \\
Trp-Met-Gly (4) & $1.5( \pm 0.1)^{\mathrm{a}}$ & $2.3( \pm 0.1) \times 10^{5}$ \\
AMPhe-Met (5) & $101.6( \pm 1.5)^{\mathrm{a}}$ & $5.3( \pm 1.1) \times 10^{8}$ \\
\hline
\end{tabular}

a Fraction of $0.50 \mathrm{mM}$ peptide that remains after 24

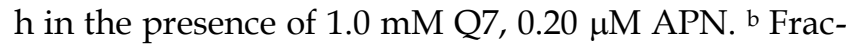
tion of 0.10 Phe-Met that remains after $24 \mathrm{~h}$ in the

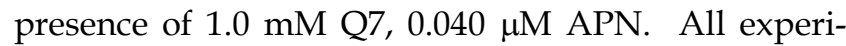
ments were performed at $37^{\circ} \mathrm{C}$ in $10 \mathrm{mM}$ ammonium phosphate, $\mathrm{pH} 7.2$, and values were determined by integrated peak intensities in the HPLC traces of samples after $24 \mathrm{~h}$. ${ }^{\mathrm{c}}$ Mean values measured from at least three ITC experiments at $27^{\circ} \mathrm{C}$ in $10 \mathrm{mM}$ ammonium phosphate, $\mathrm{pH}$ 7.2. Standard deviations are given in parentheses.

It is interesting to consider how the increased concentrations of Q7 impeded initial degradation of the substrate at the $5 \mathrm{~min}$ time point. In the samples containing $0.50 \mathrm{mM}$ and $1.0 \mathrm{mM}$ Q7, appreciable quantities of the $\mathrm{Q} 7 \bullet \mathbf{2}$ complex had not yet formed, but enzymatic activity was clearly retarded. Higher Q7:1 ratios were needed to form and protect the $\mathrm{Q} 7 \bullet 2$ product at $3 \mathrm{~h}$ and $24 \mathrm{~h}$. These results suggest that Q7 also has a small inhibitory effect by binding to the enzyme but that inhibition of proteolysis is primarily governed by binding to the substrate, as observed for LAP. ${ }^{15}$

The highest affinity binding sites for Q7 on natural peptides are at N-terminal Phe, Tyr, and Trp residues $\left(\mathrm{K}_{\mathrm{a}} \sim 10^{5}-10^{7} \mathrm{M}^{-1}\right)$; other potential binding sites have much weaker affinities. ${ }^{9}$ In order to assess the extent to which Q7 can protect these residues from APN digestion, we prepared a series of peptides with different aromatic N-termini and measured the extent of their protection by Q7 in the presence of APN. Phe-Met (2), Tyr-Met (3), and Trp-Met-Gly (4), each at $0.50 \mathrm{mM}$, were incubated for $24 \mathrm{~h}$ with $1.0 \mathrm{mM}$ Q7 and $0.20 \mu \mathrm{M}$ APN and then analyzed by HPLC. Table 1 gives the residual quantities of peptides that remain after $24 \mathrm{~h}$ and compares these values to their binding affinities for Q7, as determined by isothermal titration calorimetry (ITC). These data reveal a direct correlation between binding affinity and extent of protection by Q7, and they demonstrate that Q7

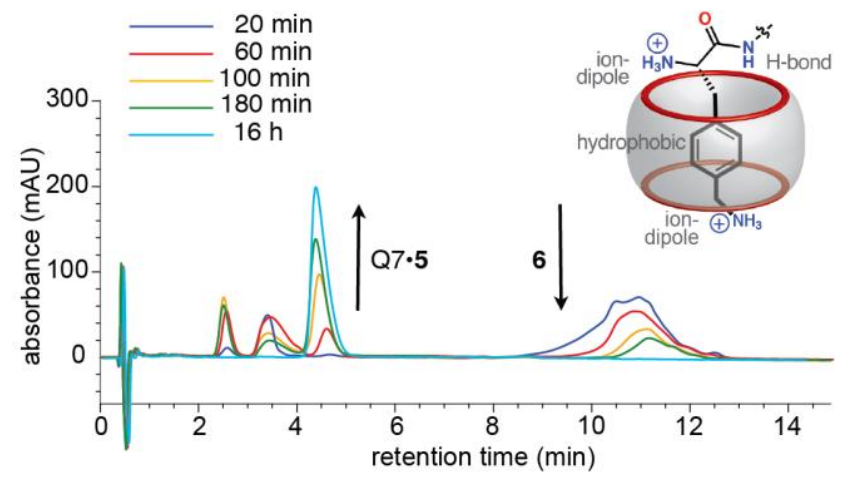

Figure 3. Analytical HPLC traces of the reaction of 0.5 $\mathrm{mM}$ Thr-Gly-Ala-AMPhe-Met (6) with $0.20 \mu \mathrm{M}$ in the presence of $0.83 \mathrm{mM}$ Q7 at $37{ }^{\circ} \mathrm{C}$ in $10 \mathrm{mM}$ ammonium phosphate, $\mathrm{pH}$ 7.2.

inhibits APN degradation most effectively at a Phe residue. Given the clear substrate-inhibition mechanism, we should be able to increase the ratio of Q7:2 in order to increase the extent of protection by Q7. To test this hypothesis, we increased the ratio of Q7:2 to 10:1 and, in fact, observed complete retention of peptide 2 after $24 \mathrm{~h}$ (Table 1).

Considering the correlation between the extent of peptide protection and its binding affinity to Q7, we were interested in examining a stronger binding site. N-terminal Phe is the preferred epitope in native peptides, but we found recently that Q7 can bind with nanomolar affinity to peptides containing a 4-aminomethyl phenylalanine (AMPhe) residue at the $\mathrm{N}$-terminal position (Figure 3). ${ }^{20}$ Indeed, we observed quantitative protection of AMPhe-Met (5) $\left(K_{a}=5.3 \times 10^{8} \mathrm{M}^{-1}\right)$ from APN digestion in the presence of two equivalents of Q7 (Table 1).

Given the strong protection of AMPhe-Met (5) by Q7, we wanted to test the ability of Q7 to inhibit the complete digestion of a peptide containing a non-terminal AMPhe residue. Therefore, we synthesized the pentapeptide Thr-Gly-Ala-AMPheMet (6) and followed its degradation by APN using analytical HPLC (Figure 3). We observed substantial retention of starting material until at least $3 \mathrm{~h}$, with complete disappearance of starting material by $16 \mathrm{~h}$. Up to $3 \mathrm{~h}$, three new peaks in the 
2-5 min range grew, but at $16 \mathrm{~h}$ only a single peak remained (at $\sim 4 \mathrm{~min}$ ). This remaining peak correlates exactly with a standard sample of the Q7•5 complex and was confirmed to be the Q7 $\bullet 5$ complex by ESI-MS (see Supporting Information). In the absence of Q7, the peptide was digested completely into amino acids.

These results demonstrate that Q7 can completely inhibit the removal of Phe and AMPhe residues from the $\mathrm{N}$-terminal position of peptides by APN. In doing so, a peptide containing an internal Phe or AMPhe is cropped down to that residue. Therefore, Q7 imparts predictable sequence-specificity to an otherwise non-specific exopeptidase and enables the production of a single peptide product. This constitutes a novel approach to peptide processing that is specific, quantitative, and effective under mild conditions ( $\mathrm{pH} 7.2$ buffer, $37^{\circ} \mathrm{C}$ ). Proteolysis is inhibited only when APN has reached a target residue. Conversely, if APN is inhibited, then a rare highaffinity epitope (e.g., the N-terminal Phe) has been uncovered, and the resulting peptide product is bound by Q7. Therefore, this method may also facilitate the recognition and labeling of peptides at a single site. ${ }^{12,21-24}$ It remains to be seen whether the method will work with longer polypeptides or with other receptor/protease pairs. Work in this area is ongoing and will be reported in due course.

\section{ASSOCIATED CONTENT}

Supporting Information. Experimental details, HPLC data, mass spectra, isothermal titration calorimetry. This information is available free of charge via the internet at http://pubs.acs.org.

\section{AUTHOR INFORMATION}

\section{Corresponding Author}

aurbach@trinity.edu

\section{Notes}

The authors declare no competing financial interest.

\section{ACKNOWLEDGMENTS}

This paper is dedicated to Prof. David A. Tirrell on the occasion of his $60^{\text {th }}$ birthday. We thank Dr. Frank Truong for inspiration, Dr. John Ngo for helpful discussions, and Mr. Joel Adablah for technical assistance. Financial support from the Welch Foundation (W-1640), the National Science Foundation (CHE-0748483 and CHE-0957839), and the Henry Dreyfus Teacher Scholars program is gratefully acknowledged.

\section{REFERENCES} 2078

(1) Gilmore, J. M.; Washburn, M. P. J. Proteomics 2010, 73 ,

(2) Thiede, B.; Hohenwarter, W.; Krah, A.; Mattow, J.; Schmid, M.; Schmidt, F.; Jungblut, P. R. Methods 2005, 35, 237.

(3) Craik, C. S.; Page, M. J.; Madison, E. L. Biochem. J. 2011, 435, 1.

(4) Turner, A. J. Handbook of Proteolytic Enzymes, 2nd Ed.; Elsevier: San Diego, 2004.

(5) Taylor, A. FASEB J. 1993, 7, 290.

(6) Lee, J. W.; Samal, S.; Selvapalam, N.; Kim, H.; Kim, K. Acc. Chem. Res. 2003, 36, 621.

(7) Lagona, L.; Mukhopadhyay, P.; Chakrabarti, S.; Isaacs, L. Angew. Chem. Int. Ed. 2005, 44, 4844.

(8) Masson, E.; Ling, X.; Joseph, R.; Kyeremeh-Mensah, L.; Lu, X. RSC Adv. 2012, 2, 1213. 664.

(9) Urbach, A. R.; Ramalingam, V. Isr. J. Chem. 2011, 51,

(10) Bush, M. E.; Bouley, N. D.; Urbach, A. R. J. Am. Chem. Soc. 2005, 127, 14511.

(11) Heitmann, L. M.; Taylor, A. B.; Hart, P. J.; Urbach, A. R. J. Am. Chem. Soc. 2006, 128, 12574.

(12) Chinai, J. M.; Taylor, A. B.; Ryno, L. M.; Hargreaves, N. D.; Morris, C. A.; Hart, P. J.; Urbach, A. R. J. Am. Chem. Soc. 2011, 133.

(13) Rekharsky, M. V.; Yamamura, H.; Inoue, C.; Kawai, M.; Osaka, I.; Arakawa, R.; Shiba, K.; Sato, A.; Ko, Y. H.; Selvapalam, N.; Kim, K.; Inoue, Y. J. Am. Chem. Soc. 2006, $128,14871$.

(14) Rekharsky, M. V.; Yamamura, H.; Ko, Y. H.; Selvapalam, N.; Kim, K.; Inoue, Y. Chem. Commun. 2008, 2236.

(15) Hennig, A.; Ghale, G.; Nau, W. M. Chem. Comm. 2007, 1614.

(16) Ghale, G.; Kuhnert, N.; Nau, W. M. Nat. Prod. Commun. 2012, 7, 343.

(17) Zhang, X.; Xu, W. Curr. Med. Chem. 2008, 15, 2850.

(18) Addlagatta, A.; Gay, L.; Matthews, B. W. Biochemistry 2008, 47, 5303.

(19) In this sample, we believe that $50 \%$ of the peptide was digested quickly due to the limiting quantity of Q7, and an additional $13 \%$ was digested noticeably due to the lower concentration of $Q 7$.

(20) Logsdon, L. A.; Schardon, C. L.; Ramalingam, V.; Kwee, S. K.; Urbach, A. R. J. Am. Chem. Soc. 2011, 133, 17087.

(21) McGovern, R. E.; Fernandes, H.; Khan, A. R.; Power, N. P.; Crowley, P. B. Nature Chem. 2012, 4, 527.

(22) Wehner, M.; Janssen, D.; Schafer, G.; Schrader, T. Eur. J. Org. Chem. 2006, 138.

(23) Yin, H.; Hamilton, A. D. Angew. Chem. Int. Ed. 2005, $44,4130$. 2479. 
Insert Table of Contents artwork here

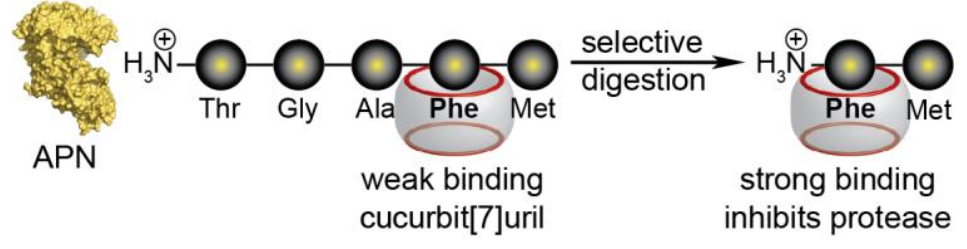

